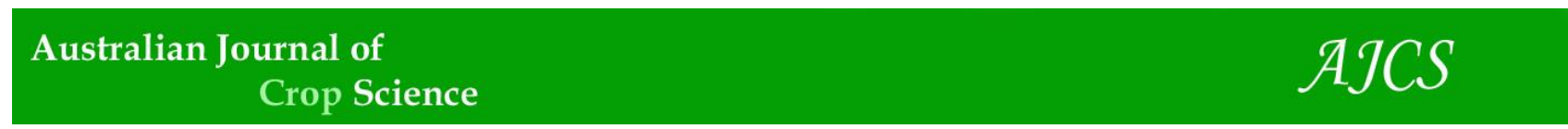

AJCS 14(03):3000-3005 (2020)

ISSN:1835-2707

doi: 10.21475/ajcs.20.14.03.p2119

\title{
Population structure and spatial distribution of Copaifera langsdorffii Desf.
}

\author{
Priscila Bezerra de Souza', Bruno Aurélio Campos Aguiar', Giuseppe Varaschim Neto', Euclides Figueredo \\ Fonseca', Bárbara Maria Martins Santos ${ }^{1}$, Lorena Gama Teixeira', Débora Lopes Farias', Bárbara Suelma \\ Souza Costa ${ }^{2}$, Yasmim de Andrade Ramos', Raquel Marchesan ${ }^{3}$, Marcos Vinicius de Melo Amorim', Hygor \\ Gomes de Almeida Sousa', Maristela Lima Figueiredo Guimaraes Epifanio', Rubens Ribeiro da Silva²
}

1Forest Seed Laboratory, Federal University of Tocantins, Gurupi, Tocantins, Brazil
${ }^{2}$ Soil Laboratory, Federal University of Tocantins, Gurupi, Tocantins, Brazil
${ }^{3}$ Laboratory of Technology of Madeira, Federal University of Tocantins, Gurupi, Tocantins, Brazil

*Corresponding author: priscilauft@uft.edu.br

Abstract

The aim of this work was to analyze the population structure and the spatial distribution of Copaifera langsdorffii Desf. in two areas of the Cerrado biome. The study was carried out in two physiognomies of the Cerrado biome: cerrado sensu stricto and cerradão, both located in the southern region of the state of Tocantins. The spatial distribution was evaluated using Morisita and dispersion indices, as well as the population structure of $C$. langsdorffii. We quantified 318 individuals of $C$. langsdorffii in the two studied areas. There were 200 individuals sampled in the cerrado sensu stricto and 118 in the area of cerradão. Regarding the type of spatial distribution of individuals of $C$. langsdorffii, the value found for the Morisita index was 2.67 in the physiognomy of cerrado sensu stricto, suggesting grouped spatial distribution $(I>1)$. The dispersion index calculation showed that, in fact, the spatial distribution of the individuals sampled in the two areas was the grouped type; for the area of cerrado sensu stricto, the variance $\left(\mathrm{S}^{2}\right)$ found was 24.21 and for the cerradão it was 9.67 , higher than their means 10.00 and 9.67 respectively. By analyzing the age structure of the population of $C$. langsdorffii, we found a typical trend of the inverted-J curve, suggesting that the areas studied are self-regenerating communities composed of young and developing individuals.

Keywords: diametric structure; dispersion index; Morisita index; copaiba.

Abbreviations: DBH_Diameter at breast height; DI_Dispersion index; MI_ Morisita index.

Introduction

Brazil is remarkable in terms of its continental dimensions; it occupies $47.3 \%$ of the total area of South America, in addition to the fact that it has an immense biological diversity distributed across six biomes. Within these biomes, the cerrado is the second largest, with an area of occupation equivalent to 204.7 million hectares (IBGE, 2004). The geographical position of the cerrado biome, located in the central portion of Brazil, gives rise to the richness of its vegetation, owing to its areas of contact with all other Brazilian biomes, except for that of the Campo Sulino/Pampa biome. Therefore, it is common to identify species in the Cerrado biome that are naturally found in other types of vegetation (Brazilian Flora, 2016).

The vegetation in Tocantins is marked by the influence of the two largest Brazilian biomes: the Amazon forest and the cerrado; $72 \%$ of its vegetation is composed of remnants of the cerrado biome (Brazil, 2015), thereby possessing one of the most well-preserved portions (Sano et al., 2010), and also one of those most threatened by the expansion of the agricultural frontier (Klink; Machado, 2005).

It should be noted that in southern Tocantins, there is a predominance of the physiognomy cerrado sensu stricto, characterized by $10 \%$ to $60 \%$ arboreal cover, with trees that reach up to seven meters in height (Felfili; Fagg, 2007). Furthermore, within the cerrado biome, there are other types of environment ranging from forest formations (including cerradão, riparian and gallery forests) to rural formations ("dirty" and "clean" fields) (Miguel et al., 2016). The native flora of the cerrado can be efficiently used by farmers as economic alternatives (Felfili et al., 2004), because this biome includes a variety of species with potential for both timber and non-timber uses. The species Copaifera langsdorffii is highly resistant to natural degradation and is widely used in carpentry (Rudd, 1991); the oil-resin produced by this species is widely used by indigenous populations, as well as the cosmetics and pharmaceutical industries, representing a major export to Europe and the United States (Setzer, 2018).

C. langsdorffii, also known as copaiba, copaibeira, pau d'óleo, among others, is a tree species with great variation in size, depending on its habitat (Santos et al., 2016). In Brazil, the species occurs in the caatinga, cerrado, Atlantic forest and Amazon forest biomes. It is characterized by the presence of compound leaves, that are pinnate, alternating, 
and spiral with 4 to 12 alternating or opposing leaflets (Lorenzi, 2008).

Data regarding the spatial distribution of the populations is important, because this knowledge enhances understanding of the local ecology, assisting planning and delimiting of areas for the purposes of environmental conservation (Hutchings, 1986). These data also aid in the development of statistical methods and sample delineations, providing basic strategies for forest management and conservation. Trees may present three basic patterns of spatial distribution, defined by the Morisita and scatter indices: random, grouped and uniform. Factors including environmental conditions as well as natural and anthropogenic disturbances interfere with the spatial pattern of plant populations and may interfere with growth rates, seed production, leaf area, root length and ultimate tree size (Santos et al., 2016).

According to the literature, size structure of individuals is a criterion for classification of species into ecological groups. To identify population size, the "inverted-J" method is most often used. This method is often used to indicate population stability or increase as well as its capacity for selfregeneration and reproduction under the canopy (SilvaJunior, 1999).

Therefore, the objective of this study was to analyze the population structure and spatial distribution of $C$. langsdorffii in an area of cerrado sensu stricto located in southern Tocantins, Brazil.

\section{Results and Discussion}

\section{Population Structure}

We quantified 318 individuals of $C$. langsdorffii in the two studied areas. There were 200 individuals sampled in the cerrado sensu stricto area and 118 in the cerradão area. Regarding the type of spatial distribution of individuals of $C$. langsdorffii, the value found for the Morisita index was 2.67 in the physiognomy of cerrado sensu stricto, suggesting grouped distribution ( $\mathrm{Ml}>1$ ). The same pattern was reported by Santos et al. (2016) in the Araripe-CE natural forest, Legendre and Fortin (1989) and Thomas and Kunin (1999) stated that, in general, living beings are distributed in a grouped manner in nature. In the physiognomy of cerradão, the value found for the Morisita index was 1.13, suggesting grouped spatial distribution $(\mathrm{MI}>1)$. The same pattern was found by Faria et al. (2013) for Brosimum gaudichaldii Trecul in the Cerrado of Mato Grosso.

The dispersion index showed that the spatial distribution of the individuals was grouped, because the variance $\left(S^{2}\right)$ was 79.78, higher than its mean 53. Hay et al. (2000) published a comparative study of data found in their own work and those of other studies of the spatial distribution of five species of the cerrado biome, noting that, in general, these species also presented grouped distributions (Table 1).

It is very important to understand the distribution pattern of the species, especially those used for commercial purposes, because this knowledge facilitates silvicultural management (Martins et al., 2003). With most of the species that appear in grouped form, e.g. C. langsdorffii Desf., it is necessary to maintain some individuals at commercial size to perpetuate the natural distribution of the species; only then can timber and non-timber products be maintained in a sustainable and manageable manner into the future (Almeida et al., 2012). To measure the auto-regenerative and reproductive capacity of the canopy of the study areas in the municipality of Cariri do Tocantins, individuals are distributed in diametric classes of typical models of inverted- or negative exponential-J patterns. According to Silva Júnior (1999), whenever there is a J-inverted pattern, with a decreasing number of individuals from the first to the last class, there is a positive balance between recruitment and mortality, demonstrating that the site is self-regulating.

The diametric distribution of living individuals from the cerradão presented a J-inverted form (Figure 1). In this area, we observed a predominance of young individuals, as approximately $71 \%$ of the total of individuals presented DBH of up to $14 \mathrm{~cm}$. In this area, there was a tendency for larger diameters and higher heights. In the area of the cerradão, no individuals were found in the height class of $0-3 \mathrm{~m}$, with the majority of individuals being observed in the classes of 7.4 to $11.8 \mathrm{~m}$ with approximately $57 \%$ of the total sampled individuals (Figure 2). In areas of cerradão, Andrade et al. (2002) observed the distribution of the diameter of living and dead individuals in J-inverted format. They found that $90 \%$ of the living individuals had maximum diameter of 13 $\mathrm{cm}$ and height of $5 \mathrm{~m}$.

Considering the context, we observed a larger number of individuals in the first height and DBH than in the others. The graph plotted a J-inverted or negative exponential form, that is, there was a high concentration of individuals in the classes of smaller diameter with marked reduction in the direction of the larger classes. From this it can be inferred that the $C$. langsdorffii individuals are in regeneration process, suggesting that the cerrado sensu stricto and cerradão are basically composed of young individuals in full development (Figures 1 and 2). This same pattern of diametric distribution was verified in a Cerrado forest remnant located in the municipality of Gurupi - TO (Silva; Souza, 2017).

The diametric distribution of living individuals from the cerrado sensu stricto also presented J-inverted form (Figure 3 ). In the class of diameters 3 to $8.5 \mathrm{~cm}$ comprises $77.5 \%$ of the trees sampled in the area. We observed in the cerrado sensu stricto, that the height classes 5.2 to $9.6 \mathrm{~m}$ were more significant than in the other areas, representing 66\% (Figure 4).

The individuals in the final diametric class in relation to height and DCH were equivalent to those of adult individuals that were reproductively mature, capable of producing fruits/seeds and reproduction; therefore, their existence allows natural regeneration of $C$. langsdorffii., and young individuals are greatly important to ensure the maintenance of the population (Antonini; Nunes-Freitas, 2004).

\section{Materials and Methods}

\section{Characterization of the study area}

The study was carried out on a private property, known as Chácara Santa Rita, in Cariri do Tocantins, southern Tocantins, latitude 11ㅇ' $47.49^{\prime \prime} \mathrm{S}$, longitude 4913'50.42" W (Figure 5). The study area is located at $249 \mathrm{~m}$ above sealevel, with average annual precipitation and temperature of approximately $1.5 \mathrm{~mm}$ and $27 \stackrel{\circ}{\circ}$, respectively. November to 
Table 1. Spatial distribution of eight species of the cerrado biome, defined by the dispersion and Morisita indices.

\begin{tabular}{llll}
\hline Species & Method & Result & Reference \\
\hline Copaifera langsdorff Desf. & $\mathrm{DI}, \mathrm{MI}$ & Grouped & This study \\
Myrciaria tranciflora Berg & $\mathrm{MI}$ & Grouped & Amaral et al., 2015 \\
Copaifera langsdorff Desf. & $\mathrm{MI}$ & Grouped & Oliveira-Filho et al., 1996 \\
Pterodon pubescens (Benth.) Benth. & $\mathrm{DI}$ & Grouped & Hay et al., 2000 \\
Caryocar brasilienses Cambess & $\mathrm{DI}$ & Grouped & Silberbauer-Gottsberger and Eiten, 1987 \\
Hancornia speciosa Gomes & $\mathrm{MI}$ & Grouped & Moura et al., 2011 \\
Ocotea odorifera Rohwer & $\mathrm{MI}$ & Grouped & Amaral et al.,2015 \\
Sclerolobium paniculatum Vogel & $\mathrm{DI}$ & Grouped & Hay et al., 2000 \\
Copaifera langsdorff Desf. & $\mathrm{MI}$ & Grouped & Resende et al., 2003 \\
Syagrus comosa (Mart.) Mart. & $\mathrm{DI}$ & Random & Hay et al., 2000 \\
Syagrus flexuosa (Mart.) Becc. & $\mathrm{DI}$ & Grouped & Hay et al., 2000 \\
Syagrus romanzoffiana Glassman & $\mathrm{DI}$ & Grouped & Amaral et al., 2015 \\
\hline
\end{tabular}
(DI = dispersion index; $\mathrm{MI}$ = Morisita index. Source: Hay et al., 2000)

\section{cerradão}

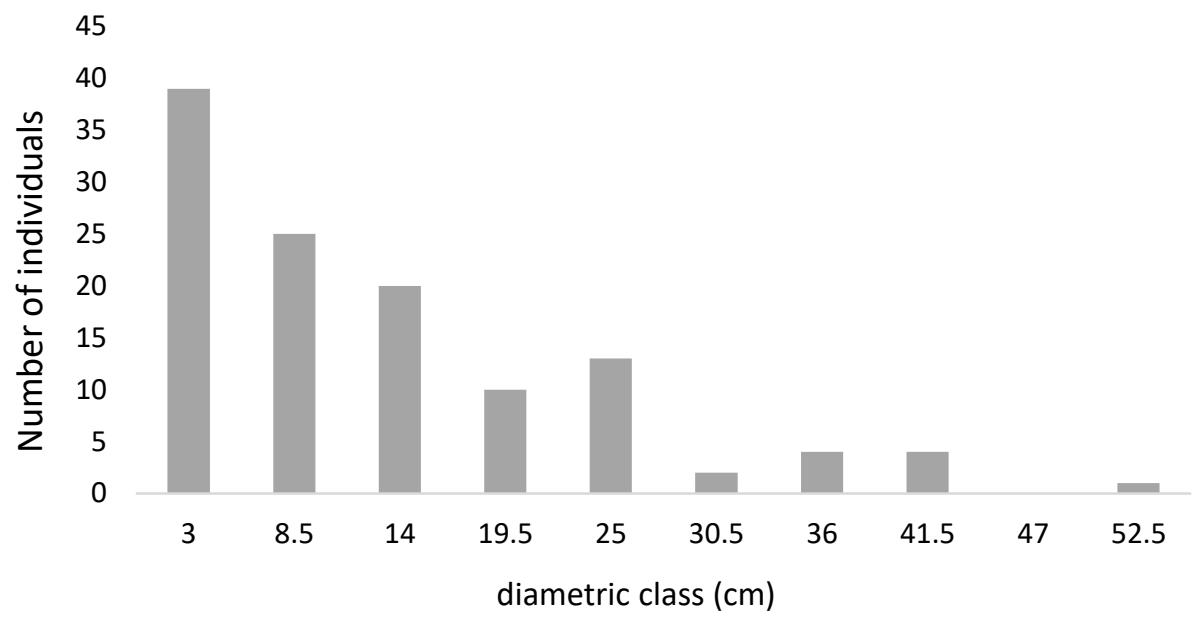

Fig 1. Distribution of $C$. langsdorffii diametric grades in the cerradão, in southern Tocantins.

\section{cerradão}

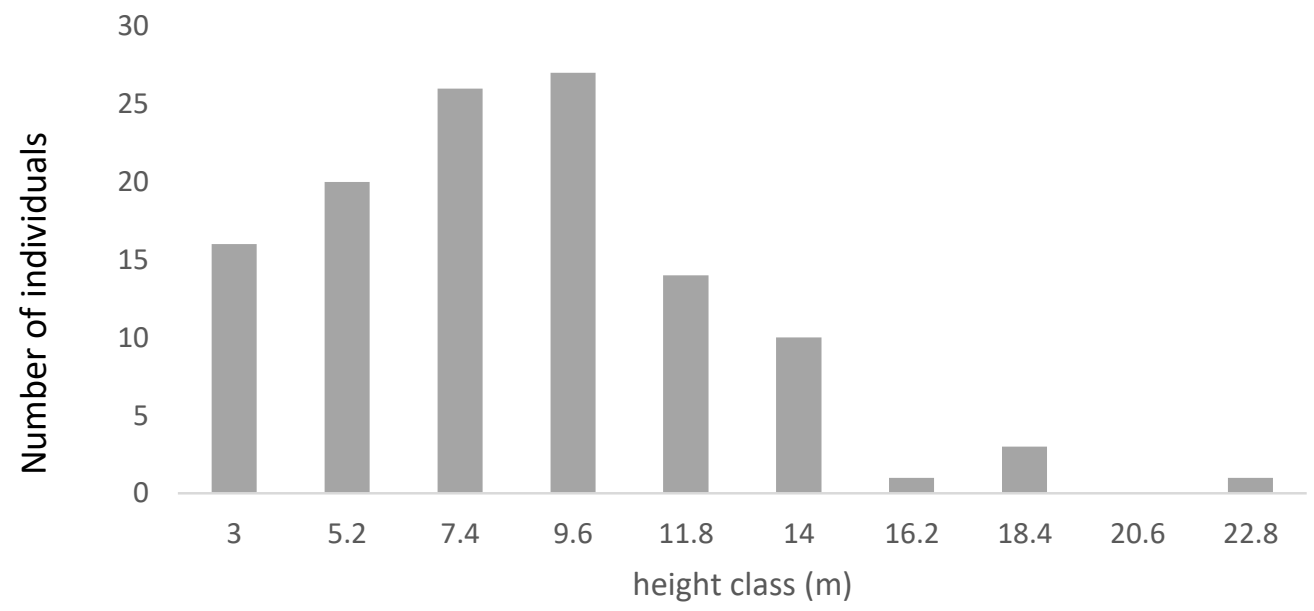

Fig 2. Distribution of $C$. langsdorffii height grades in the cerradão, in southern Tocantins. 


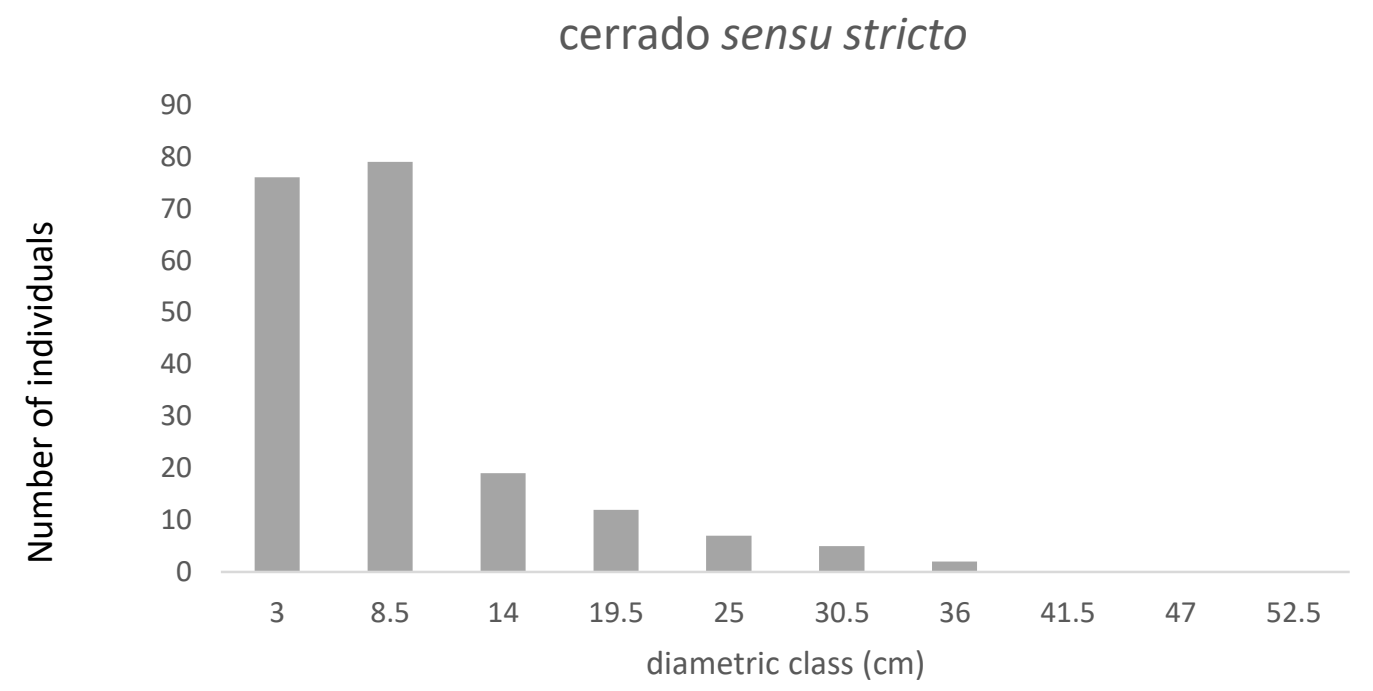

Fig 3. Distribution of $C$. langsdorffii diametric grades in the cerrado sensu stricto, in southern Tocantins.

\section{cerrado sensu stricto}

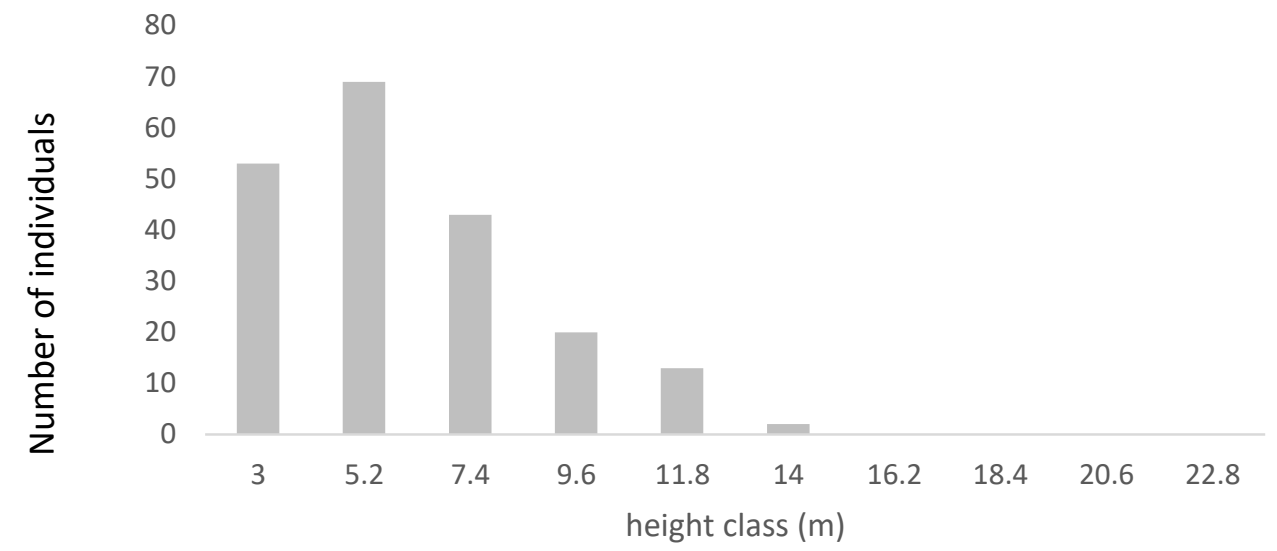

Fig 4. Distribution of $C$. langsdorffii height grades in the cerrado sensu stricto, in southern Tocantins.

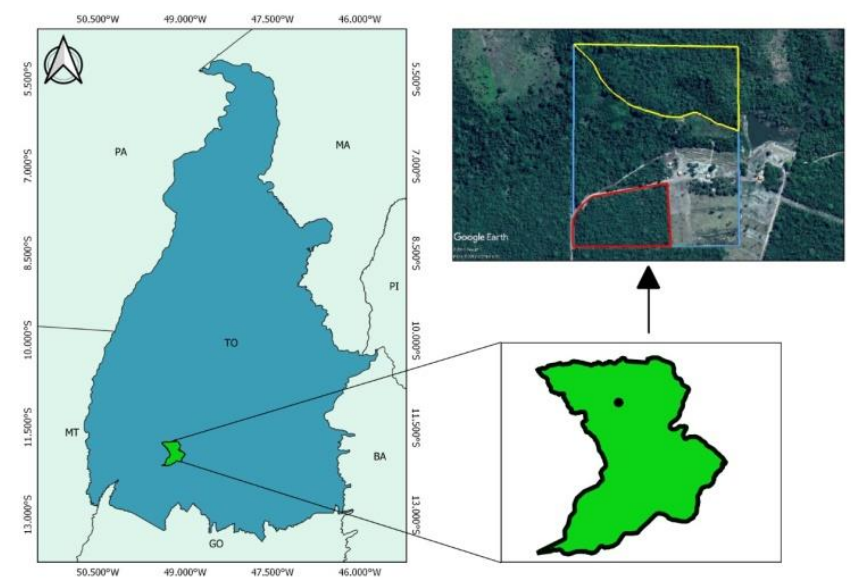

Fig 5. Map of the study area in the cerradão, in southern Tocantins. 
April are the rainiest months and May to October are the driest. According to Köppen, the climate of the region is type B1wA'a humid, with moderate water deficiency (Seplan, 2012).

The total area of the study area is 23 hectares, parts of which are managed in various ways. Of the total area, 14.46 hectares are allocated to legal reservation or permanent preservation areas, 4.5 hectares are designated for cultivated pasture, 0.6 hectares are designated for passion fruit cultivation and 3.44 hectares are designated for alternative use.

The study area was selected because it presents forest fragments of the cerrado biome such as the physiognomy cerrado sensu stricto and cerradão, as well as for the abundance of individuals of the species $C$. langsdorffii.

\section{Evaluation of individuals}

The studied area was selected for presenting forest fragments as cerrado sensu stricto and cerradão, and a forest inventory was taken in the two areas where the fixed area sampling method was adopted, the vegetation of the shrub-tree component was quantitatively evaluated by the plots method (Mueller - Dombois; Ellenberg, 1974). Twenty sample plots were installed in each experimental area with dimensions of $20 \times 50 \mathrm{~m}\left(1000 \mathrm{~m}^{2}\right)$ each, i.e., 2.0 ha of sample area, where 50 subplots of $10 \times 10 \mathrm{~m}\left(100 \mathrm{~m}^{2}\right)$ were demarcated within each plot. The distribution of these plots occurred systematically throughout the study areas of cerrado sensu stricto and cerradão, being $20 \mathrm{~m}$ apart. The size of the plots used in this work was standardized according to the project "Biogeografia do Bioma Cerrado Biogeography of the Cerrado Biome" (Felfili; Silva Junior, 1992).

In the plots, we sampled all live shrub-trees individuals with diameter at breast height (DBH) greater than $3 \mathrm{~cm}$, measuring the circumference at breast height ( $\mathrm{CBH}$ measured at $1.30 \mathrm{~m}$ from the soil). For the measurement of $\mathrm{DCH}$, a measuring tape graduated in centimeters was used. The relationship of $\mathrm{DCH}$ to $\mathrm{CCH}$ was determined by the following formula:

$D C H=\frac{C C H}{\pi}$ (1)

The heights of the trees were measured using a ruler graduated in meters.

All shrub-arboreal individuals of $C$. langsdorffii were catalogued by collecting their geographic coordinates, using a Garmin Etrex GPS device.

\section{Phytosociological parameters}

Spatial distribution was determined by the dispersion and Morisita indices (Gomes; Ferreira, 2004). The dispersion index (DI) can be established from the mean and variance values as follows:

RANDOM PATTERN: $S^{2}=X$

GROUPED PATTERN: $S^{2}>X$

UNIFORM PATTERN: $S^{2}<X$

where $S$ is the variance of the number of individuals and $X$ is the mean number of individuals.

The Morisita index (MI) is described by equation 3:

$M I=q\left[\frac{\Sigma n(n-1)}{N(N-1)}\right]$ where $\mathrm{q}$ is the total number of plots sampled, $\mathrm{n}$ is the number of individuals in the $\mathrm{i}$-th plot and $\mathrm{N}$ is the total number of individuals sampled.

According to these calculations, the spatial pattern should be considered random when $\mathrm{MI}<1$, regular or uniform if $\mathrm{Ml}$ $=1$, and aggregated or grouped if $\mathrm{MI}>1$.

The age distribution of the population was analyzed by constructing graphs of height and diameter distribution, where the parameters were taken from the formula $A / K$, where $A$ is the amplitude between the highest and lowest values, and $\mathrm{K}$ is the number of classes.

The basic data obtained from the 20 plots of 2.0 ha were analyzed for the purpose of obtaining the matrix that relates the number of trees per hectare of the $\mathrm{i}$-th species in the j-th diameter class. The individuals sampled were distributed in ten diameter classes, with intervals of $5.5 \mathrm{~cm}$ and by height classes, in intervals of $2.2 \mathrm{~cm}$. The diametrical distribution was done by means of the sampled individuals of each species within the diametric class to which they belonged, where to generate the graphs and tables were used the Microsoft Office Excel and Fitopac version 2.1.2.

\section{Conclusion}

The spatial distribution found for the population of $C$. langsdorffii demonstrated a grouped distribution pattern, defined on the basis of the Morisita $(\mathrm{MI}>1)$ and dispersion indices $\left(S^{2}>X\right)$. The age structure of $C$. langsdorffii was an inverted-J type, suggesting that the study area has a population in the process of self-regeneration, composed of young individuals in full development.

\section{Acknowledgements}

The Federal University of Tocantins - UFT for the grant of the Research Productivity Grant of UFT and for the translation aid and/or Publication of Scientific Articles.

\section{References}

Almeida LS, Gama JRV, Oliveira FA, Carvalho JOP, Gonçalves DCM, Araújo GC (2012) Fitossociologia e uso múltiplo de espécies arbóreas em floresta manejada, Comunidade Santo Antônio, município de Santarém, Estado do Pará. Acta Amaz. 42: 185-194.

Amaral MK, Pellico Netto S, Lingnau C, Figueiredo Filho A (2015) Evaluation of the Morisita index for determination of the spatial distribution of species in a fragment of Araucaria forest. Appl Ecol Env Res. 13: 361-372.

Andrade LAZ, Felfili JA, Violatti L (2002) Fitossociologia de uma área de cerrado denso na RECOR-IBGE, Brasília - DF. Acta Bot Bras. 16: 225-240.

Antonini RD, Nunes-Freitas AF (2004) Estrutura populacional e distribuição espacial de Miconia prasina DC (Melastomataceae) em duas áreas de Floresta Atlântica na Ilha Grande, RJ, Sudeste do Brasil. Acta Bot Bras. 18: 671676.

BRASIL (2015) Ministério do Meio Ambiente. Mapeamento do Uso e Cobertura do Cerrado: Projeto Terra Class Cerrado 2013. Brasilia: MMA, v.1, p. 67. 
BFG-The Brazil Flora Group (2016) Growing knowledge: an overview of seed plant diversity in Brazil. Rodriguésia. 66: 1085-1113.

Faria RAPG, Coelho MFB, Albuquerque MCF, Azevedo RAB (2013) Distribuição espacial e estrutura populacional de Brosimum gaudichaudii Trécul no Cerrado de Mato Grosso, Brasil. Enciclopédia Biosfera. 9: 3386-3395.

Felfili JM, Fagg CW (2007) Floristic composition, diversity and structure of the" cerrado" sensu stricto on rocky soils in northern Goiás and outhern Tocantins, Brazil. Braz J Bot. 30: 375-385.

Felfili JM, Silva Junior MCD (1992) Floristic composition, phytosociology and comparison of cerrado and gallery forests at Fazenda Água Limpa, Federal District, Brazil. In Nature and dynamics of forest-savanna boundaries (P.A. Furley \& J.A. Proctor, eds.). Chapman \& Hall, London.

Felfili JM, Silva Júnior MC, Sevilha AC, Fagg CW, Walter BMT, Nogueira PE, Rezende AV (2004) Diversity, floristic and structural patterns of cerrado vegetation in Central Brazil. Plant Ecology. 175: 37-46.

Gomes AS, Ferreira SP (2004) Apostila de análise de dados ecológicos. Universidade Federal Fluminense. Niterói - RJ.

Hay JD, Bizerril MX, Calouro AM, Costa EMM, Ferreira AA, Gastal MLDA, Goes Junior CD, Oliveira SA, Manzan DF, Martins CR, Monteiro JMG, Rodrigues MCM, Seyffarth JAS, Walter BMT (2000) Comparação do padrão da distribuição espacial em escalas diferentes de espécies nativas do cerrado, em Brasília, DF. Rev Bras Bot. 23: 341-347.

Hutchings MJ, (1986) A estrutura das populações de plantas. Em: Crawley, MJ (ed.). Ecologia vegetal Blackwell Scientific Publications, Londres.

IBGE (2014) Mapa de biomas do Brasil. Escala 1: 5.000.000. Rio de Janeiro: IBGE. Available at http://mapas.ibge.gov.br/biomas2/ viewer.htm. Acessed: November 04, 2018.

Klink CA, Machado RB (2005) Conservation of the Brazilian cerrado. Conser biol. 19: 707-713.

Legendre P, Fortin MJ (1989) Spatial pattern and ecological analysis. Vegetation. 80: 107-138.

Lorenzi H (2008) Árvores brasileiras: manual de identificação e cultivo de plantas arbóreas nativas do Brasil. 5.ed. Nova Odessa: Instituto Plantarum.

Martins SS, Couto L, Machado CC, Souza AL (2003) Efeito da exploração seletiva em uma floresta estacional semidecidual. Rev Árvore. 27: 65-70.

Miguel EP, Rezende AV, Leal FA, Pereira RS, MELO RRD (2016) Floristic-structural characterization and successional group of tree species in the Cerrado biome of Tocantins state, Brazil. Revista Caatinga. 29: 393-404.

Moura NF, Chaves L, Vencovsky R, Naves RV, de Aguiar AV, Moura MF (2011) Genetic structure of mangaba (Hancornia speciosa Gomes) populations in the cerrado region of central Brazil. Biosci J. 27: 473-481.

Mueller-Dombois D, Ellenberg H (1974) Aims and methods of vegetation ecology. New York: John Wiley \& Sons.

Oliveira-Filho AT, Camisão-Neto AA, Volpato MML (1996) Structure and dispersion of four tree populations in an area of montane semideciduous forest in southeastern Brazil. Biotropica. 8: 762-769.

Resende JCF, Kink CA, Schiavini I (2003) Spatial heterogeneity and its influence on Copaifera langsdorffii Desf. (Caesalpiniaceae). Braz Arch Biol Technol. 46: 405414.

Rudd VE (1991) Caesalpinioideae. In: Flora of Ceylon, Volume 7 (eds. M.D Dassanayake and FR Fosberg). Smithsonian Institution and National Science Foundation, Washington DC, USA.

Santos JEG, Da Silva MAP, Da Silva DL (2016) Estrutura, dispersão e distribuição espacial de Copaifera langsdorfii Desf. na floresta nacional do Araripe, Ceará, Brasil. Cadernos de Cultura e Ciência. 15: 72-81.

Setzer, WN (2018) Copaifera of the Neotropics: A Review of the Phytochemistry and Pharmacology. Int J Mol Sci. 19(5).

Sano EE, Rosa R, Brito, JLS (2010) Land cover mapping of the tropical savanna region in Brazil. Environ Monit Assess. 166: 113-124.

SEPLAN - Secretária do Planejamento. Diretoria de Zoneamento Ecológico- Economico - (DZE) (2012) Base de dados geográfico do TO. Versão 2012, Palmas- TO. Available at http://seplan.to.gov.br/ Acessed: October 13, 2012.

Silberbauer-Gottsberger I, Eiten G (1987) A hectare of cerrado: I. General aspects of the trees and thick-stemmed shrubs. Phyton. 27: 55-91.

Silva GO, Souza PB (2017) Fitossociologia e estrutura diamétrica de um fragmento de cerrado sensu stricto, Gurupi-TO. Desafios. 3: 22-29.

Silva-Júnior MC (1999) Composição florística, fitossociologia e estrutura diamétrica na Mata de galeria do Monjolo, Reserva Ecológica do IBGE (Recor), DF. Boletim do Herbário Ezechias Paulo Heringer, 4: 1-11.

Thomas CD, Kunin WE (1999) The spatial structure of populations. J Anim Ecol. 68: 647-657. 